\section{Great American Smokeout - November 21, 2019}

The American Cancer Society's Great American Smokeout is an annual event that encourages smokers to make a plan to quit smoking (https://www.cancer.org/healthy/stay-away-fromtobacco/great-american-smokeout.html). The 44th annual Great American Smokeout will occur on November 21, 2019.

In the more than 50 years since the first Surgeon General's report on the health consequences of smoking, cigarette smoking among U.S. adults has declined by approximately two thirds (1). A report in this issue of $M M W R$ documented that in 2018, $13.7 \%$ of U.S. adults were current cigarette smokers, which is the lowest prevalence recorded since monitoring began in 1965 (2). However, the report also found that 34.2 million adults still smoke cigarettes and that marked disparities in tobacco use persist across population groups (2).

Smoking remains the leading preventable cause of disease, disability, and death in the United States (1); however, smokers can and do quit smoking, and today there are more former smokers than current smokers $(1,2)$. Among current U.S. adult smokers, nearly $70 \%$ want to quit smoking, and approximately half made a quit attempt in the past year $(2,3)$. Using counseling and medications increases the chances of quitting (3). Support for quitting smoking is available at 800-QUIT-NOW (800-784-8669). CDC's Tips From Former Smokers campaign (https://www.cdc. gov/tips) and the National Cancer Institute's smokefree.gov (https://smokefree.gov) offer additional resources.

\section{References}

1. US Department of Health and Human Services. The health consequences of smoking - 50 years of progress: a report of the Surgeon General. Atlanta, GA: US Department of Health and Human Services, CDC; 2014. https:// www.cdc.gov/tobacco/data_statistics/sgr/50th-anniversary/index.htm

2. Creamer MR, Wang TW, Babb S, et al. Tobacco product use and cessation indicators among adults-United States, 2018. MMWR Morb Mortal Wkly Rep 2019;68:1013-9.

3. Babb S, Malarcher A, Schauer G, Asman K, Jamal A. Quitting smoking among adults - United States, 2000-2015. MMWR Morb Mortal Wkly Rep 2017;65:1457-64. https://doi.org/10.15585/mmwr.mm6552a1

\section{Tobacco Product Use and Cessation Indicators Among Adults - United States, 2018}

\begin{abstract}
MeLisa R. Creamer, $\mathrm{PhD}^{1}$; Teresa W. Wang, $\mathrm{PhD}^{1}$; Stephen Babb, $\mathrm{MPH}^{1}$; Karen A. Cullen, $\mathrm{PhD}^{2}$; Hannah Day, $\mathrm{PhD}^{2}$; Gordon Willis, $\mathrm{PhD}^{3}$; Ahmed Jamal, $\mathrm{MBBS}^{1}$; Linda Neff, $\mathrm{PhD}^{1}$
\end{abstract}

Cigarette smoking is the leading cause of preventable disease and death in the United States (1). The prevalence of adult cigarette smoking has declined in recent years to $14.0 \%$ in 2017 (2). However, an array of new tobacco products, including e-cigarettes, has entered the U.S. market (3). To assess recent national estimates of tobacco product use among U.S. adults aged $\geq 18$ years, CDC, the Food and Drug Administration (FDA), and the National Cancer Institute analyzed data from the 2018 National Health Interview Survey (NHIS). In 2018,

\section{INSIDE}

1020 Disparities in Receipt of Eye Exams Among Medicare Part B Fee-for-Service Beneficiaries with Diabetes — United States, 2017

1024 Update on Vaccine-Derived Poliovirus Outbreaks — Worldwide, January 2018-June 2019

1029 Progress Toward Poliomyelitis Eradication Pakistan, January 2018-September 2019

1034 Risk Factors for E-Cigarette, or Vaping, Product Use-Associated Lung Injury (EVALI) Among Adults Who Use E-Cigarette, or Vaping, Products Illinois, July-October 2019

1040 Evaluation of Bronchoalveolar Lavage Fluid from Patients in an Outbreak of E-cigarette, or Vaping, Product Use-Associated Lung Injury - 10 States, August-October 2019

1042 QuickStats

Continuing Education examination available at https://www.cdc.gov/mmwr/cme/conted_info.html\#weekly.

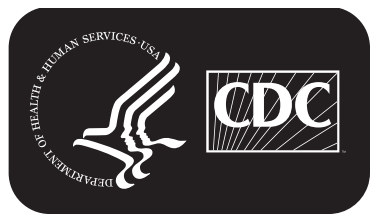

